\title{
Key Performance Indicators for integrating Maintenance Management and Manufacturing Planning and Control
}

\author{
Harald Rødseth, Jan Ola Strandhagen, Per Schjølberg \\ Department of Production and Quality Engineering, \\ Norwegian University of Science and Technology, Trondheim, Norway \\ \{harald.rodseth, ola.strandhagen, per.schjolberg\} @ntnu. no
}

\begin{abstract}
Based on current research and industrial experience, it is found to be a challenge with "silos" where an asset with several disciplines have poor collaboration and result in sub-optimised outcome in production. A structured approach to tackle this situation is through the concept of Integrated Planning (IPL). The purpose of this article is through literature study to identify relevant KPIs within both of the disciplines Manufacturing, Planning \& Control (MP\&C) and Maintenance Management. As a result, Overall Equipment Effectiveness (OEE) is used in both of the disciplines and throughput time is an essential KPI in MP\&C. Finally, a KPI structure which integrates MP\&C and Maintenance Management is developed in this article.
\end{abstract}

Keywords: Key Performance Indicators (KPIs) · Manufacturing Planning \& Control · Maintenance Management

\section{Introduction}

In industry it has been identified a need for improving the integration between the different disciplines, and has in Oil \& Gas industry been labelled as Integrated Operations (IO) [20]. In particular, an own research programme called "Center for Integrated Operations in the petroleum industry" has defined IO as integration of people, organisations, work processes and information technology to make smarter decisions [7]. In order to operationalise IO it is crucial to also integrate all the planning disciplines in O\&G industry into an Integrated Planning (IPL) concept [19]. The challenge for operating IPL is that the different domains in an organisation function more often than not as separate "silos" $[19,20]$. This phenomena occurs in an organisation where an asset with several disciplines and departments performs activities which affects each other [21]. However, due to poor collaboration between these disciplines and departments, the result in production is rather sub-optimised. This challenge is also apparent in manufacturing industry with several challenges found in a literature study [18]. The main finding was that the Manufacturing Planning and Control (MP\&C) system is today not well integrated with maintenance planning system. Even worse is that maintenance is only considered on a tactical and operation level in manufacturing, leaving out maintenance for strategic decisions in the organisation. Despite these

adfa, p. 1, 2011.

(C) Springer-Verlag Berlin Heidelberg 2011 
challenges, initiatives in production exist to integrate production and maintenance. Such an example is Lean Production which includes the maintenance concept Total Productive Maintenance (TPM). According to Shah and Ward [23], TPM is of relevance in order to achieve high level of equipment availability. However, TPM also aims at maximizing the equipment effectiveness not only through increased availability in terms of preventing breakdowns, but also reduction of speed losses and quality defects occurring from process activities [1]. In this article the disciplines Maintenance Management, MP\&C is evaluated within IPL.

From a maintenance perspective, lack of IPL may have several unfortunate impacts, such as increased maintenance backlog due to unplanned maintenance activities [25], sub-optimal prioritizing of activities and unnecessary production downtime [20], and Enterprise Resource Planning (ERP) systems which has not integrated the maintenance function into production planning [18].

An essential approach for successfully operationalise IPL is applying suitable Key Performance Indicators (KPIs) [2]. In fact it is argued that plans need to be coupled with a mechanism which can monitor the effectiveness of the plan and the progress in order to take corrective actions when needed [2]. Today, there exist vast sources of literature within KPIs for providing terminology, purpose and operation and identification of them [6], [8], [12], [15], [16]. A KPI is defined by Eckerson [8] to be " $a$ metric measuring how well the organisation or an individual performs an operational, tactical or strategic activity that is critical for the current and future success of the organisation". This definition is also aligned in Maintenance management where KPI is described by Palmer to be a metric which is determined by the company to be particularly important [16]. Furthermore, Palmer also describes a metric to be an indicator or measure of maintenance performance. In both of the disciplines Maintenance Management and MP\&C, KPIs are essential for decision making. In Maintenance Management an own standard of KPIs has been developed, covering economic, technical and organisational KPIs [6]. Examples of an economic maintenance KPI would be the ratio between preventive maintenance cost and total maintenance cost. Furthermore, in MP\&C KPIs such as throughput time is essential and is measured as manufacturing throughput time per part (MTTP) [10].

This article evaluate through a literature study existing KPIs for both Maintenance Management and MP\&C. Furthermore, the common KPI for these disciplines are identified and structured as a set of KPIs.

The remainder of this article is structured as follows; in Section 2 existing KPIs within both Maintenance Management and MP\&C is investigated. Further in Section 3 an integrated set of KPIs are proposed for Maintenance Management and MP\&C. Finally, concluding remarks are drawn in Section 4. 


\section{Key Performance Indicators in maintenance and manufacturing}

\subsection{Identification and evaluation within Maintenance Management}

Within Maintenance Management, several maintenance KPI and structural frameworks exist [6], [17], [26], [28], [31]. A specific standard for maintenance KPIs have been established, denoted as EN-NS 15341 [6]. From a Maintenance Management perspective, this standard is of relevance when outlining maintenance objectives and KPIs [13]. The overall aspect of this standard is shown in Figure 1. The indicator level divides the indicators into application for the plant production (level 1), production line (level 2) and the specific equipment (level 3). Moreover, the indicator group is divided into economic, technical and organisational groups.

Fig. 1. Structure of maintenance KPIs in NS-EN 15341 adapted from [6].

\begin{tabular}{|c|c|c|c|c|}
\hline $\begin{array}{l}\text { External } \\
\text { Influencing } \\
\text { factors }\end{array}$ & $\begin{array}{lr}\begin{array}{l}\text { Indicator } \\
\text { Groups }\end{array} & \begin{array}{r}\text { Level } \\
\text { Grator }\end{array}\end{array}$ & $\begin{array}{l}\text { Level 1: } \\
\text { Production plant }\end{array}$ & $\begin{array}{l}\text { Level 2: } \\
\text { Production line }\end{array}$ & $\begin{array}{l}\text { Level 3: } \\
\text { Equipment }\end{array}$ \\
\hline \multirow{3}{*}{$\begin{array}{l}\text { Internal } \\
\text { Influencing } \\
\text { factors }\end{array}$} & Economic & $6 \mathrm{KPIs}$ & $9 \mathrm{KPIS}$ & $10 \mathrm{KPIS}$ \\
\hline & Technical & $5 \mathrm{KPIS}$ & $2 \mathrm{KPIS}$ & $14 \mathrm{KPIS}$ \\
\hline & Organisational & $8 \mathrm{KPIS}$ & $2 \mathrm{KPIS}$ & $21 \mathrm{KPIS}$ \\
\hline
\end{tabular}

This standard has also been evaluated in the context of Value-driven maintenance [27]. The authors propose here a dedicated level 0 in the KPI structure which are the most essential indicators to prioritize for implementation. Some of KPIs has also been selected as KPIs within World Class [22] and is presented in Table 1. The selection of these KPIs is based on expert judgement from both academia and industry. When these KPIs have reached a specific target, the companies are considered to be a company which practice World Class Maintenance (WCM). A proposed definition of WCM is inspired by Wiremans expression "best maintenance practice" [30] where WCM then is defined as "the maintenance practices that enable a company to achieve a competitive advantage over its competitors in the maintenance process" .

Table 1. Maintenance KPIs in World Class Maintenance adapted from Schjølberg \& Baas [22].

\begin{tabular}{lll}
\hline No. & Maintenance KPI & Description of KPI \\
\hline 1 & Total Maintenance Cost / Asset Replacement & $\begin{array}{l}\text { Describes if the company has } \\
\text { too high maintenance costs. }\end{array}$
\end{tabular}

2 Average inventory value of maintenance maIs used to evaluate if the interials / Asset Replacement Value ventory value of maintenance is too large. 
3 Time for preventive maintenance / Total time for maintenance

4

Total Maintenance Cost / Total turnover

5

Time for critical corrective maintenance / Total time for maintenance

6

Planned and predictive time for maintenance / Total time for maintenance

Actual operation time / Required operation time
Indicates the time portion of preventive maintenance.

Describes the cost of maintenance compared of the turnover of the company.

Indicates the time portion for critical corrective maintenance.

Describes the amount of time in maintenance organisation used for proactive work in terms of planned and predictive maintenance.

This indicator shows the operational availability in production.

$\mathrm{OEE}=$ Availability rate $*$ Performance rate * Quality rate.

The maintenance concept Total Productive Maintenance (TPM) has influenced this list with the OEE indicator. This indicator is the most central KPI in TPM and was introduced by Nakjaima [14] and is endorsed today through establishments of both industry standard [5] and user guide [11]. In fact, based on a thorough literature study performed by Simões et al. [24], OEE was ranked to be number 2 out of 37 maintenance performance measures applied in the maintenance organisation. Furthermore, OEE is regarded to be an essential KPI in Asset Management which is a new concept for WCM. In fact, it is dedicated as an asset indicator for strategic, tactical and operational purpose [29]. OEE measures time losses in production in terms of the six big losses which comprise machine breakdown (1), waiting (2), minor stoppages (3), reduced speed (4), scrap (5) and rework (6) [11]. In addition it is important to include a KPI which is leading in nature and measure the maintenance process instead of the maintenance outcome. A proposed leading maintenance KPI is \% maintenance work order with due date compliance [2]. A decrease of this KPI can indicate a future machinery breakdown, reduced speed in production and defects and will therefore be a leading KPI for OEE. 


\subsection{Identification and evaluation within Manufacturing Planning \& Control}

Within MP\&C specific KPIs have been developed for MRP which measures issues such as lateness, mean tardiness and percent tardy [9]. However, these KPI are mostly relevant for MRP and more generic KPIs should be applied. A comprehensive list of KPIs within MP\&C is presented in Table 2 for this purpose. The selection of these KPIs is based on existing indictors applied in lean production [12]. In addition throughput time should be of high importance within MP\&C. This is also supported as an important KPI by Olhager and Selldin [15] who measure the performance of speed in production. Alfnes et al. [3] also endorse throughput time who consider both production flow and work in progress to be areas within operations of excellence. The reason to endorse throughput time as an essential KPI within MP\&C, is based on evaluating the flow perspective of products in manufacturing. If the throughput time decreases of the products, the faster will the customer pay for the finished goods. In addition OEE will sustain a machine perspective where the machine adds more value to the customer. This KPI will also be of importance in MP\&C as well as it is regarded one of the most important KPIs within WCM.

Table 2. Important KPIs within MP\&C

\begin{tabular}{|c|c|c|}
\hline No. & $\begin{array}{l}\text { KPI for MP\&C } \\
\text { and source }\end{array}$ & Explanation \\
\hline 1 & $\begin{array}{lcr}\text { Dock To } & \text { Dock } \\
\text { (DTD) [12] } & \end{array}$ & $\begin{array}{l}\text { Is measured by counting the total inventory, including raw } \\
\text { materials, Work-in-process and finished goods, and divid- } \\
\text { ing bye the average rate of products shipped. }\end{array}$ \\
\hline 2 & $\begin{array}{l}\text { First Time } \\
\text { Through (FTT) }\end{array}$ & $\begin{array}{l}\% \text { of total units that pass through the value stream on the } \\
\text { first pass without rejected. }\end{array}$ \\
\hline 3 & $\begin{array}{l}\text { Floor Space (Sav- } \\
\text { ings) [12] }\end{array}$ & $\begin{array}{l}\text { Area of space of production, including among others, } \\
\text { space for raw material, work-in-process, and finished } \\
\text { goods inventories. }\end{array}$ \\
\hline 4 & $\begin{array}{l}\text { On-Time } \\
\text { ment }[12]\end{array}$ & $\begin{array}{l}\% \text { of the scheduled customer orders volumes actually } \\
\text { shipped on schedule. }\end{array}$ \\
\hline 5 & $\begin{array}{l}\text { WIP-to-SWIP } \\
{[12]}\end{array}$ & (Total Inventory on the Cell)/Standard Cell Inventory \\
\hline 6 & OEE [12] & Desc \\
\hline 7 & $\begin{array}{l}\text { Sales per person } \\
{[12]}\end{array}$ & $\begin{array}{l}\text { Calculated as sales amount divvied by the number of peo- } \\
\text { ple in the value stream. }\end{array}$ \\
\hline 8 & $\begin{array}{l}\text { Average cost per } \\
\text { unit [12] }\end{array}$ & $\begin{array}{l}\text { Is described by all the costs of the value stream for the } \\
\text { week and dividing by the quantity of units shipped to } \\
\text { customers within in a time period. }\end{array}$ \\
\hline 9 & $\begin{array}{l}\text { Throughput time } \\
{[10]}\end{array}$ & $\begin{array}{l}\text { The length of time from when material enters a produc- } \\
\text { tion facility until it exits. }\end{array}$ \\
\hline
\end{tabular}




\section{Towards Integrated KPIs}

For MP\&C the throughput time (MTTP) is of importance. Some studies have been performed of reducing the throughput time [4], [10]. In particular in Johnson's study [10] indicates the importance of maintenance in reducing the throughput time. When consider OEE, issues in terms of reduction of setup time (waiting time loss), scrap and rework (scrap), time in operation (reduced speed) and processing variability through improving preventive maintenance (machine breakdown) was identified in this study.

When comparing the KPIs from MP\&C in Table 2 and Maintenance Management in Table 1 OEE is one KPI applied in both of these disciplines. In order to construct KPIs which are integrated for MP\&C and Maintenance Management, it is therefore proposed to combine the KPIs OEE and MTTP. In addition it is proposed to have one KPI from each discipline. From Maintenance Management the KPI \% maintenance work order with due date compliance. Since OEE influence the MTTP, \% maintenance work order with due date compliance can indicate a future increase of MTTP. From MP\&C a leading KPI should also be applied.

A summary of the KPI structure for leading and lagging KPIs for the diciplines MP\&C and Maintenance Management is shown in Figure 2.

Fig. 2. Structure of leading and lagging KPIs for MP\&C and Maintenance Management

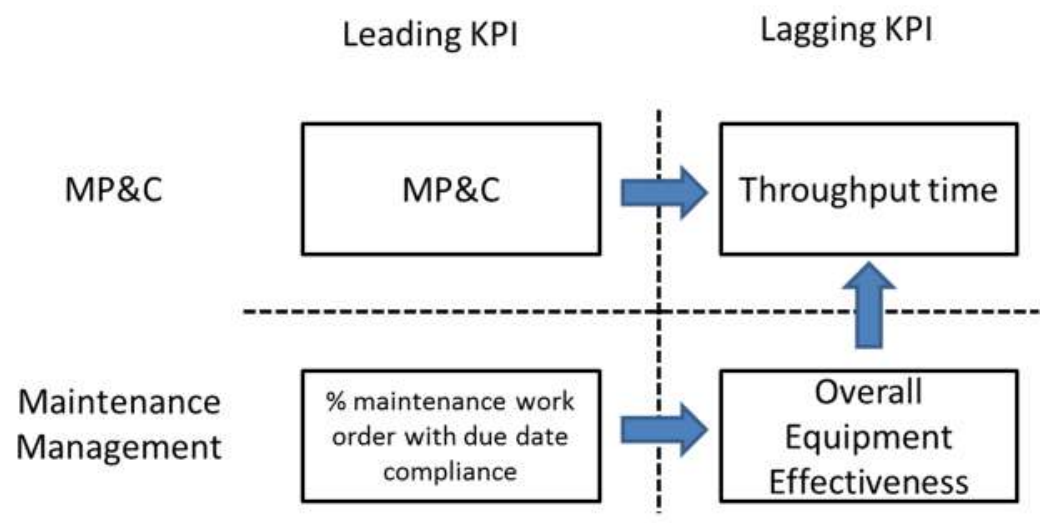

A proposed approach for operationalising this concept should be based on more integrated use of the company's maintenance management model and material requirements planning. The maintenance department might experience too low amount of maintenance work order with due date compliance, i.e. too high maintenance backlog. If the maintenance plan itself is not poor, this leading KPI should be communicated to MP\&C in order to update the MRP calculations. In addition, it should also be considered to reduce today's throughput time in order to improve the maintenance backlog. Furthermore, The OEE indicator should be used for root cause analysis where time used for maintenance or even the need for maintenance activities can be reduced. This 
could also improve the maintenance backlog and the throughput time. Even though this type of improvement work is taking place in today's WCM companies, the KPI structure should be considered as an important support tool where the effects and the awareness of IPL is better documented.

\section{Concluding remarks}

This article has through a literature study both in MP\&C and Maintenance Management identified both the common KPI OEE and established a relationship with leading and lagging KPIs and has been developed as a KPI structure. The expected result of the KPI structure will not only result in reduced throughput time, but also improved coordination between maintenance management and MP\&C. From a maintenance perspective, this will e.g. lead to better understanding of why the maintenance backlog level in short term should not be reduced in order to achieve high throughput time. In long-term this should also lead to awareness for MP\&C why the throughput time should be temporary reduced in order to allow for reducing the maintenance backlog and over time increase the throughput time. Further research will require several case studies in manufacturing companies that will further evaluate and improve this KPI structure.

\section{References}

1. Ahuja IPS, Khamba JS Total productive maintenance: literature review and directions. The International Journal of Quality \& Reliability Management 25 (7):709-756 (2008).

2. Al-Turki UM, Ayar T, Yilbas BS, Sahin AZ Integrated Maintenance Planning in Manufacturing Systems. Springer International Publishing, Cham (2014).

3. Alfnes E, Dreyer H, Strandhagen J The Operations Excellence Audit Sheet. In: Koch T (ed) Lean Business Systems and Beyond, vol 257. IFIP - The International Federation for Information Processing. Springer US, pp 129-141 (2008).

4. Barker RC Development of demand pull type control methods: The design of block action production control methods to reduce throughput time and improve supply chain synchronization. Production Planning \& Control 12 (4):408-417 (2001).

5. BLOM OEE Industry Standard. Blom Consultancy, (2003).

6. CEN NS-EN 15341: Maintenance - Maintenance Key Performance Indicators. (2007).

7. Center I Annual Report 2013 - Center for Integrated Operations in the petroleum industry. (2013).

8. Eckerson WW Performance dashboards: measuring, monitoring, and managing your business. J. Wiley, Hoboken, N.J. (2006).

9. Enns ST MRP performance effects due to lot size and planned lead time settings. International Journal of Production Research 39 (3):461-480 (2001).

10. Johnson DJ A framework for reducing manufacturing throughput time. Journal of Manufacturing Systems 22 (4):283-298 (2003).

11. Koch A, Oskam A OEE for the production team: the complete OEE user guide. FullFact, Lieshout (2007). 
12. Maskell BH, Baggaley B Practical lean accounting: a proven system for measuring and managing the lean enterprise. Productivity Press, New York (2011).

13. Meland O, Rødseth $\mathrm{H}$ Maintenance management models - A crucial tool for achieving a world-class maintenance function? In: 11th International Probabilistic Safety Assessment and Management Conference and the Annual European Safety and Reliability Conference 2012, PSAM11 ESREL 2012, June 25, 2012 - June 29, 2012, Helsinki, Finland, 2012. 11th International Probabilistic Safety Assessment and Management Conference and the Annual European Safety and Reliability Conference 2012, PSAM11 ESREL 2012. Probablistic Safety Assessment and Management (IAPSAM), pp 191-200 (2012).

14. Nakajima S Introduction to TPM: Total Productive Maintenance. Productivity Press, New York (1988).

15. Olhager J, Selldin E Manufacturing planning and control approaches: market alignment and performance. International Journal of Production Research 45 (6):1469-1484 (2007).

16. Palmer D Maintenance planning and scheduling handbook. McGraw-Hill, New York (2013).

17. Parida A, Kumar U Maintenance performance measurement (MPM): Issues and challenges. Journal of Quality in Maintenance Engineering 12 (3):239-251 (2006).

18. Powell D, Rødseth H ICT-Enabled Integrated Operations: Towards a Framework for the Integration of Manufacturing- and Maintenance Planning and Control. Paper presented at the Advances in Production Management Systems: Sustainable Production and Service Supply Chains, Penn State University, 2013-09-09 - 2013-09-12 (2013)

19. Ramstad LS, Halvorsen K, Wahl AM Improved Coordination with Integrated Planning: Organisational Capabilities. Society of Petroleum Engineers (2010).

20. Rosendahl T, Hepsø V Integrated operations in the oil and gas industry. Business Science Reference, Hershey, Pa. (2013).

21. Rødseth H, Schjølberg P The Importance of Asset Management and Hidden Factory for Integrated Planning. Advanced Materials Research 1039:577-584 (2014).

22. Schjølberg P, Baas C Kartlegging av vedlikehold og driftssikkerhet i norsk industri 2002, vol NTNU 200302. Instituttet, Trondheim (2003).

23. Shah R, Ward PT Defining and developing measures of lean production. Journal of Operations Management 25 (4):785-805 (2007).

24. Simões JM, Gomes CF, Yasin MM Reviews and case studies a literature review of maintenance performance measurement a conceptual framework and directions for future research. Journal of Quality in Maintenance Engineering 17 (2):116-137 (2011).

25. Sleire H, Brurok T Opportunity Based Maintenance in offshore operations. Condition Monitoring and Diagnostics Engineering Management COMADEM 2009 (2009).

26. Sondalini M Useful Key Performance Indicators for Maintenance. (2005)

27. Stenström C, Parida A, Kumar U, Galar D Performance indicators and terminology for value driven maintenance. Journal of Quality in Maintenance Engineering 19 (3):222-232 (2013).

28. Vaisnys P, Contri P, Beith M Benchmarking study of maintenance performance monitoring practices. Summary report. European Commision, Luxembourg: Office for Official Publications of the European Communities (2007).

29. Van der Lei T, Herder P, Wijnia Y Asset Management: The State of the Art in Europe from a Life Cycle Perspective. Springer Netherlands, Dordrecht (2012).

30. Wireman $\mathrm{T}$ Maintenance management and regulatory compliance strategies. Industrial Press, New York (2003).

31. Wireman T Developing performance indicators for managing maintenance. Industrial Press, New York (2005). 